\title{
Admissibility of the Defendant's Criminal Records at Trial
}

\author{
James B. Jacobs \\ Criminal Law and Procedure, New York University School of Law, New York, USA \\ Email: james.jacobs@nyu.edu
}

Received March 19 ${ }^{\text {th }}$, 2013; revised April 24 ${ }^{\text {th }}$ 2013; accepted May $16^{\text {th }}, 2013$

\begin{abstract}
Copyright (c) 2013 James B. Jacobs. This is an open access article distributed under the Creative Commons Attribution License, which permits unrestricted use, distribution, and reproduction in any medium, provided the original work is properly cited.
\end{abstract}

\begin{abstract}
The jury trial, which is a hallmark of the Anglo-American adversary system, requires close attention to the evidence that it is permissible for the lay jurors to hear. No evidentiary issue has proved more contentious than the admissibility of witnesses', especially defendants', prior criminal history because of concern that the lay jurors might prejudicially infer present guilt from past criminality. This article explains the complex evidentiary rules for admitting criminal history to prove guilt and to impeach witness credibility. It suggests that inquisitorial trial procedure, which historically has been unconcerned that judges know about the defendant's prior criminal history while they are determining present guilt may have to restrict admissibility of such evidence as lay juries become more common.
\end{abstract}

Keywords: Prior Crimes Evidence; Jury Trial; Rules of Evidence; European Trials

\section{Introduction}

“The State may not show defendant's prior trouble with the law, specific criminal acts, or ill name among his neighbors, even though such facts might logically be persuasive that he is by propensity a probable perpetrator of the crime. The inquiry is not rejected because character is irrelevant; on the contrary, it is said to weigh too much with the jury, and to so over-persuade them as to prejudge one with a bad general record and deny him a fair opportunity to defend against a particular charge. The overriding policy of excluding such evidence, despite its admitted probative value, is the practical experience that its disallowance tends to prevent confusion of issues, unfair surprise, and undue prejudice (Michelson v. United States, 335 US 469, 1948)."

"Somewhere along the way the system lost track of the simple truth that it is supposed to be fair and to protect those who obey the law while punishing those who break it. You expect the trial to be a search for truth; you find that it is a performance orchestrated by lawyers and the judge, with the jury hearing only half the facts...

The jury is never told that the defendant has two prior convictions for the same offense and has been to prison three times for other crimes (President's Task Force, 1982)."

European law and policy treats an individual's history of criminal convictions as personal information that is entitled to privacy protection. The US, and to a lesser extent the UK, treat prior convictions as essentially public information. Therefore, it is curious that, when it comes to the admissibility at trial of a defendant's or witness' prior convictions, the US and European positions are reversed. European "inquisitorial" procedure requires that the defendant's prior convictions be made part of the case file, which is available to the judges determining the defendant's guilt or innocence. Indeed, French trials begin with the prosecutor reading out loud the defendant's prior convictions. By contrast, the US has a complex web of evidentiary rules limiting the trier of fact's (judge or jury) opportunity to find out about the defendant's prior convictions, and criminal conduct ("bad acts") that did not result in conviction. This striking difference undoubtedly reflects European confidence in professional judges and the US fear that lay jurors will be un-duly swayed by evidence of the defendant's prior criminality. As civil law countries increasingly experiment with lay judges and juries, they may have to confront whether it is fair to the defendant for the panel that is deciding on guilt to have knowledge of the defendant's past crimes.

\section{The Common Law's Evidentiary Rules on Admissibility of Prior Crimes}

The common law rule was that the prosecutor could not bring out at trial the defendant's prior crimes for the purpose of persuading the jury that that defendant was guilty of the current crime. "Propensity" evidence was inadmissible because the defendant was entitled to a trial on the present charges rather than a trial on his character. It was thought that if lay jurors heard about the defendant's past criminal conduct, especially past convictions, they might be unable to fairly assess whether the evidence on the present charges proved guilt beyond a reasonable doubt. They might vote to convict because, consciously or unconsciously, they believed that the defendant was a bad or dangerous person. Moreover, they might consciously or unconsciously conclude that a defendant who "did it before, probably did it this time as well." While common sense and experience suggest that people usually act consistently with their past actions, that is not invariably true. Moreover, police have a tendency to solve "crimes" by rounding up and prosecuting "the usual suspects," i.e. people who committed similar crimes in the past. The common law rejected the conclusion that once a thief always a thief, once a swindler always a swindler. The presumption of innocence applies even to those who have been convicted in the past (Kalven \& Zeizel, 
1966). ${ }^{1}$

While the common law rule rejecting propensity evidence would seem to promote fairness and prevent unjust convictions, in some situations it defies common sense and unfairly prejudices the prosecution. For example, it seems highly relevant, albeit not determinative, that a man charged with assaulting a young girl near a school had on two previous occasions assaulted other young girls near the same school. Likewise, it seems relevant that a woman charged with complex bankruptcy fraud has previously been convicted of employing the exact same fraudulent scheme.

Thus, the common law judges began recognizing exceptions to the prohibition against allowing jurors to hear prior crime evidence. If the defendant chose to introduce his good character as a defense, the prosecutor could introduce evidence of the defendant's bad character in rebuttal. Lawyers could, on crossexamination, impeach (question the credibility of) the other side's witnesses by introducing evidence of that witness's past crimes.

Exceptions proliferated. If the defendant called to the witness stand a person who testified that the defendant enjoyed a reputation in the community for honesty and integrity, the prosecution was permitted to rebut that testimony by asking that witness if he knew about the defendant's prior convictions. Alternatively, the prosecution could call as a witness a person to testify that "saintly" defendant previously had been convicted of crimes evincing dishonesty, disregard of others' person and property and contempt for important social norms. Common law exceptions were clearly explained in an influential 1901 decision by the prestigious New York State Court of Appeals: a defendant's prior crimes and bad acts were ordinarily inadmissible at trial, except when they "tend to establish 1) motive; 2) intent; 3) the absence of mistake or accident; 4) a common scheme or plan embracing the commission of two or more crimes so related to each other that proof of one tends to establish the others; 5) the identity of the person charged with the commission of the crime on trial" (People v. Molineux, 168 N.Y. 264, 1901). These exceptions were soon codified by the drafters of $20^{\text {th }}$ century evidentiary rules.

\section{Contemporary Rules of Evidence Regarding Admissibility of the Defendant's Prior Crimes}

In the $20^{\text {th }}$ century, comprehensive rules of evidence supplanted the judge-made common law rules. The Federal Rules of Evidence (FRE) only apply to federal trials, but most states have evidence rules similar to, or even the same as, the Federal Rules. FRE 404(b) states the general prohibition against "the introduction at trial of other crimes, wrongs or acts to prove the character of a person in order to show action in conformity

\footnotetext{
${ }^{1}$ Unfortunately, there is scant empirical evidence to confirm or reject the strongly held assumption that jurors will be prejudiced against defendants with prior convictions. More than fifty years ago, the seminal Chicago Jury Project observed that, despite the jury's awareness of the defendant's criminal record, it usually voted in favor of the defendant While I don't know of any similar quantitative study in the ensuing decades, knowledgeable trial lawyers and judges tell me that it is common, perhaps even more than $50 \%$ of the time, for jurors to learn about the defendant's prior record. In bench trials, the defendant, at least in New York State, can request trial before a judge who did not preside over the pretrial hearing on the admissibility of prior record, but defendants often waive that right, counting on the ability and good faith of the trial judge not to improperly consider prior records.
}

therewith” (Weinstein \& Berger, 2006; Advisory Comm. Note to 1991 404(b); Fed. R. Evid. 403). However, the rule then proceeds to enumerate exceptions that allow prior convictions and bad acts to be introduced at trial if they constitute proof of motive, opportunity, intent, preparation, plan, knowledge, identity or absence of mistake or accident (Fed. R. Evid. 404(b); Huddleston $v$. United States, 485 US 681, 1988); United States $v$. Hurley, 755 F.2d 788 (11th Cir. 1985)). Even if the judge finds that the prior conviction or bad act falls within one of the exceptions, she should allow it to be introduced only if she finds that its prejudicial effect does not substantially outweigh its probative value (State v. Beck, 536 S.E.2d 679 (S.C. 2000)). These are necessarily subjective judgments and, if the defendant is convicted, a trial ruling admitting prior crimes or bad acts is a frequent basis for appeal. However, appeals courts give substantial deference to trial judges' rulings on such evidentiary issues.

The FRE provide for admitting into evidence both prior convictions and prior bad acts that were not prosecuted or, if prosecuted, that did not result in a conviction. Thus, in prosecuting a defendant for assaulting his wife, the prosecutor, invoking the identity and motive exceptions, may call as a witness the victim, a friend who saw the incident, or the police officer who made the arrest to testify about the previous assault (People v. Mixon, 203 A.D.2d 909 (N.Y. App. Div. 1986); People v. Dyes, 122 A.D.2d 69 (N.Y. App. Div. 1986)). ${ }^{2}$ The reasoning for admitting a prior domestic assault in a present homicide or assault trial under the intent exception is that the defendant's previous assault on the same victim he is now charged with assaulting or killing tends to show that the present violence was intended and not an accident. The trial judge may admit this evidence of a prior assault if she concludes that 1) a reasonable jury could find by a preponderance of the evidence that the defendant committed that prior assault, and 2) that the prejudicial effect of this prior crime evidence does not substantially outweigh its probative value.

The defendant's prior attack on his wife, whether resulting in a conviction or not, could also be admissible under the motive exception. A clear example of the motive exception is where Doe is charged with murdering Moe, the prosecution can introduce evidence that Doe's motive was retaliation against Moe for providing evidence that resulted in Doe's prior conviction for robbery. In the domestic violence situation, the prosecutor will argue that evidence of the defendant's prior assaults on his domestic partner should be admitted because they tend to show that he had a hostile relationship with the victim, which may give rise to motive. Thus, in People v. Bierenbaum, the New York court explained that:

"In a domestic violence homicide, as this clearly is, it is highly probative — quite often far outweighing any prejudice - that a couple's marriage was strife-ridden and that defendant previously struck and/or threatened the spouse-victim. Indeed, it has also been held that such evidence in like contexts is highly probative of the defendant's motive and is either directly related to or inextricably interwoven with the issue of his identity as the killer (People v. Bierenbaum, 748 N.Y.S.2d 563 (N.Y. App. Div. 2002)).”

\footnotetext{
${ }^{2}$ In part, the willingness to allow the prosecutor to introduce evidence of the defendant's prior violence against his wife or domestic partner demonstrates the contemporary view that, in the past, the criminal justice system did not adequately protect women from battering husbands and domestic partners.
} 
The defendant's prior conviction(s) can be introduced to prove that the defendant's mental state at the time of the crime satisfied the charged offense's mens rea (culpable mental state) requirement. For example, in prosecuting defendant Peter Poe for the crime of purposefully issuing a bad check with intent to defraud, the prosecutor might argue that Poe's prior bad check convictions are relevant to proving that, in the present case, Poe acted knowingly and intentionally, not merely inadvertently or negligently. The intent exception overlaps with the "absence of mistake or accident” exception. In effect, Poe's defense is that he issued the bad check by mistake. The prosecutor argues that Poe's previous bad check writing tends to prove that his present bad check writing was no mistake.

Consider another example of the intent/absence of mistake exception. Defendant Jill Jones is charged with shoplifting an iPad. Jones claims that she meant to pay for the iPad, but absent-mindedly left the store without stopping at the cashier to pay. The prosecutor will argue that Jones' prior shoplifting convictions should be allowed into evidence to prove that Jones intended to take the iPad without paying for it. If the judge rejects the admissibility of Jones' prior convictions and Jones is acquitted, the prosecutor has no recourse. In the US, as a matter of constitutional law, a not guilty verdict cannot be appealed.

Under the identity exception, prosecutors can introduce prior bad acts and convictions in order to prove that the defendant perpetrated the charged offense. In a South Carolina trial charging the defendant with murdering two people in a barbershop, the trial judge allowed the prosecutor to introduce evidence that the defendant had previously murdered a cab driver (State v. Cheeseboro, 346 S.C. 526, 2001). Upon conviction, the defendant appealed, claiming that the jurors should not have been permitted to hear about the previous murder. The South Carolina Supreme Court affirmed the conviction, explaining that, "The fact that the same weapon was used in both the barbershop and cab driver murders goes to show appellant's identity as the barbershop killer". The use of the same weapon in both crimes made it more likely than not that the person who committed the taxi cab murder also committed the barbershop murders.

Suppose Jack James is charged with stealing letters from a mailbox. The prosecutor's theory is that James inserted into the mailbox a device that extracts envelopes. James claims that he knows nothing about the crime. The prosecutor seeks to introduce into evidence James' two previous convictions for stealing mail from mailboxes by means of a wire device. The judge will certainly find that the strikingly similar modus operandi for the present and past crimes justifies the admissibility of the prior convictions at the present trial (United States v. Connelly, 874 F.2d 412, 416 (7th Cir. 1989)).

The preparation exception is illustrated by the prosecutor's introduction at Smith's robbery trial that Smith stole a car that he later used in the bank robbery. The car theft will almost certainly be admitted to show preparation, whether or not the defendant was convicted or even arrested for the car theft. The car theft might also be admissible under the proof-of-plan exception as evidence that the defendant planned the bank robbery in advance.

When a defendant argues as an affirmative defense that, while he committed the crime, he should not be found guilty because the police entrapped him (i.e. the police caused him to commit the crime by using unacceptable force, incentives or entreaties), the prosecution can introduce evidence to show that defendant was predisposed to commit the crime; the law enforcement agents merely provided an opportunity. The best evidence of the defendant's predisposition is prior conviction(s) for the same type of offense. For example, in United States $v$. Richardson, Richardson argued that DEA agents entrapped him into conspiring to possess drugs with intent to sell (United States v. Richardson, 764 F.2d 1514 (11th Cir. 1985)). The trial judge allowed the prosecution to introduce an electronically intercepted conversation in which Richardson admitted to an earlier cocaine sale. Richardson appealed his conviction, complaining that the jurors should not have been allowed to hear about the prior bad acts disclosed in the tape-recorded conversation. The $11^{\text {th }}$ Circuit Court of Appeals held that evidence that Richardson sold cocaine in the past was admissible to show that he was not entrapped on the present occasion (United States v. Simon, 453 F.2d 111, 115 (8th Cir. 1971)).

\section{Special Rules for Admitting Evidence of Prior Sex Offenses}

US evidence law has been powerfully effected by the widely held, but empirically contestable, belief that sex offenders have an uncontrollable predisposition for sexually deviate conduct (Leonard, 1995; Natali \& Stigall, 1996; Ojala, 1999). ${ }^{3}$ Historically, trial judges often found prior sex offense convictions admissible in a current sex offense prosecution because it established the defendant's "motive," i.e. the defendant's overpowering urge for deviate sex (United States v. Rogers, 587 F.3d 816 (7th Cir. 2009)). In 1994, Congress approved amendments to the Federal Rules of Evidence specifically applicable to the admissibility of prior sex crime convictions and bad acts (Violent Crime Control and Law Enforcement Act of 1994). FRE 413 provides that "[i] $n$ a criminal case in which a defendant is accused of a sexual assault, the court may admit evidence that the defendant committed any other sexual assault. The evidence may be considered on any matter to which it is relevant” (Fed. R. Evid. 413). In US v. Johnson, for example, the defendant was accused of sexually assaulting one passenger and two flight attendants on board an airplane. At trial, the judge permitted the prosecutor to introduce evidence of other instances where Johnson was accused of, although not prosecuted for, sexual assault (United States v. Johnson, 458 F. App' x 727 (10th Cir. 2012)). Johnson appealed his conviction on the ground that evidence of prior sexual assaults should not have been admitted at his trial. However, the appeals court held that the prosecution's prior bad act evidence satisfied the threshold requirements for FRE 413 admissibility, which re-quires the court to find that " 1 ) the defendant is accused of a crime involving sexual assault or child molestation, 2) the evidence proffered is evidence of the defendant's commission of another offense or offenses involving sexual assault or child molestation, and 3) the evidence is relevant”.

The court also rejected the defendant's argument that the prior sexual assaults should not have been admitted because they were more serious than the assaults with which he was charged in the case on appeal.

\footnotetext{
${ }^{3}$ Numerous academic commentators have criticized the special evidentiary rules on admissibility of prior sex offenses as reflecting irrational prejudice against sex offenders. The critics point out that sex offenders, as a class, have lower recidivism rates than other categories of offenders. Nevertheless, legislators have singled out sex offenders for inclusion on publicly-accessible on-line sex offender registries, special employment prohibitions and restrictions on residential choices.
} 
FRE 414 deals with the admissibility of prior convictions or uncharged criminality involving sexual molestation of a child (Fed. R. Evid. 414). It applies to cases like United States $v$. Gabe, where the defendant was charged with sexually molesting a minor. In accordance with Rule 414, the trial judge permitted the prosecution to introduce witness testimony that Gabe, in the past, had sexually assaulted another child. The appeals court agreed that the evidence was admissible because the past and present sexual assaults were highly probative of present guilt. "Both victims were young girls of six or seven years at the time of the offenses; both were related to Gabe; and the sexual nature of the offenses was similar" (United States $v$. Gabe, 237 F.3d 954 (8th Cir. 2001)). This is a good example of how powerfully prejudicial evidence of past crimes can be. Once the jurors hear about the defendant's previous child sexual assaults, they will almost certainly believe him guilty of the present charges. People with prior convictions are thus highly vulnerable to being charged with new offenses that resemble their previous offenses.

\section{Weighing Prior Crime Evidence's Probative Value against Prejudicial Effect}

FRE 403 provides that even though prior convictions and bad acts are relevant, they should not be admitted at trial if the trial judge finds that the past crimes evidence's "probative value is substantially outweighed by a danger of one or more of the following: unfair prejudice, confusing the issues, misleading the jury, undue delay, wasting time, or needlessly presenting cumulative evidence."

The trial judge must consider whether the prior crime or bad act evidence has the capacity "to arouse horror or sympathy," whether the prior crimes' remoteness in time diminishes its relevance, whether the fact sought to be proven by introduction of the past crimes is really in dispute and, even if so, whether it might be proven by other evidence (Park, 2011). In other words, the trial judge should be very cautious about admitting past crimes evidence into the trial. As the Supreme Court said in Spencer v. Texas:

"Because such evidence is generally recognized to have potentiality for prejudice, it is usually excluded except when it is particularly probative in showing such things as intent; an element of the crime; identity; malice motive... The defendant's interests are protected by limiting instructions and by the discretion residing in the trial judge to limit or forbid the admission of particularly prejudicial evidence even though admissible under an accepted rule of evidence (Spencer $v$. Texas, 385 US 554, 1967).”

\section{Judge's Cautionary Instruction to the Jury}

Having decided in favor of admitting the prior crime or bad act evidence under one of the exceptions, the judge is likely at the end of the trial to instruct the jury not to consider this evidence as proof of the defendant's criminal propensity. A recommended model instruction states that:

"You [are about to hear] [have heard] evidence that the defendant previously committed [an act] [acts] similar to [the one] [those] charged in this case. You may use this evidence to help you decide [manner in which the evidence will be used to prove identity - e.g., whether the similarity between the acts previously committed and the one[s] charged in this case suggests that the same person committed all of them]. [If you find that the evidence of other acts is not proven by the greater weight of the evidence, then you shall disregard such evidence. To prove something by the greater weight of the evidence is to prove that it is more likely true than not true. This is a lower standard than proof beyond a reasonable doubt.]

The defendant is on trial for the crime[s] charged and for [that] [those] crime[s] alone. You may not convict a person simply because you believe [he] [she] may have committed some act[s], even bad act[s], in the past (Manual of Model Criminal Jury Instructions for the District Court of the Eighth Circuit § 2.09, 2011).”

\section{Prior Convictions as an Element of the Offense}

Some federal and state criminal offenses include in the definition of the crime one or more prior convictions. To prove the defendant guilty, the prosecutor must prove beyond a reasonable doubt every element of the offense, including those prior convictions. Thus, this should not be thought of as one of the evidentiary discussed above. Unlike those exceptions, when prior convictions are admitted as part of the prosecution's responsibility for proving the elements of the charged offense there is no weighing of relevance v. prejudice. For example, a person commits felony drunk driving when, having been convicted of drunk driving within the past ten years, he or she operates a motor vehicle while intoxicated. Thus, to prove felony drunk driving, the prosecutor must prove that the defendant 1 ) committed the present offense by driving while intoxicated, and 2) had previously been convicted for driving while intoxicated. It seems likely that jurors would consider this fact highly relevant, despite the judge's instruction that they should not infer the defendant's guilt on the present charge from his previous conviction.

Consider the federal felon-in-possession law, which makes it illegal for a person who has previously been convicted of any felony to possess a firearm (maximum punishment is ten years imprisonment) (18 U.S.C. § 922 (2006)). To obtain a conviction, the prosecutor must prove that the defendant was previously convicted of a federal or state felony. The defendant is certainly disadvantaged (indeed prejudiced) by the introduction at trial of his previous criminality. In Spencer v. Texas, the defendant argued that a statute that requires proof at trial of a previous conviction violate due process of law. He appealed his conviction all the way to the US Supreme Court. He urged the Court to protect defendants from prejudice by requiring that when evidence of prior convictions is an element of an offense, that element be litigated separately from the other statutory elements, i.e. that a bifurcated trial procedure should be required. In rejecting this due process challenge, the Supreme Court stated:

"Tolerance for a spectrum of state procedures dealing with a common problem of law enforcement is especially appropriate here. The rate of recidivism is acknowledged to be high, a wide variety of methods of dealing with the problem exists, and experimentation is in progress. The common-law procedure for applying recidivist statutes, which requires allegations and proof of past convictions in the current trial, is, of course, the simplest and best known procedure.”

\section{Stipulating to the Prior Conviction}

The defendant, fearing that jurors who hear about his previ- 
ous convictions would be prejudiced against him, would normally prefer to stipulate (i.e. not contest) the fact of his previous conviction(s). However, the prosecutor is unlikely to accept the defendant's stipulation, preferring that the jury hear about the prior conviction. Whether the defendant had a right to concede the previous conviction element of the charged offense was considered by the Supreme Court in Old Chief $v$. United States (Old Chief v. United States, 519 US 172, 1997). Defendant Old Chief was charged with violating the federal felon-in-possession law. He offered to stipulate that he had previously been convicted of a felony, assault resulting in serious bodily injury. The trial judge refused to allow the stipulation and permitted the prosecution to introduce the previous felony conviction. Old Chief appealed his conviction to the Supreme Court on the issue whether a defendant has a constitutional right to waive proof of one or more elements of the offense. The Court held that ordinarily a defendant has no right to have the trial court accept his stipulation to an element of the offense:

"In sum, the accepted rule that the prosecution is entitled to prove its case free from any defendant's option to stipulate the evidence away rests on good sense. A syllogism is not a story, and a naked proposition in a courtroom may be no match for the robust evidence that would be used to prove it. People who hear a story interrupted by gaps of abstraction may be puzzled at the missing chapters, and jurors asked to rest a momentous decision on the story's truth can feel put upon at being asked to take responsibility knowing that more could be said than they have heard. A convincing tale can be told with economy, but when economy becomes a break in the natural sequence of narrative evidence, an assurance that the missing link is really there is never more than second best.”

However, the court further held that, in a felon in possession of a firearm offense, the defendant should be allowed to stipulate his ex-felon status because it would not unduly disadvantage the prosecution's narrative:

"Proving status without telling exactly why that status was imposed leaves no gap in the story of a defendant's subsequent criminality, and its demonstration by stipulation or admission neither displaces a chapter from a continuous sequence of conventional evidence nor comes across as an officious substitution, to confuse or offend or provoke reproach.”

After Old Chief, lower courts have consistently permitted the prosecutor to introduce prior convictions, despite the defendant's willingness to stipulate to them, if the prior convictions pertain to elements of the charged offense (United States $v$. Williams, 238 F.3d 871 (7th Cir. 2001); United States v. Crowder, 141 F.3d 1202 (D.C. Cir. 1998)).

\section{Impeachment by Evidence of Prior Conviction or Bad Act}

So far we have been examining whether the prosecutor can introduce prior convictions or uncharged criminality to prove its case against the defendant. However, the introduction of prior crimes evidence also comes into the trial when either the prosecutor or the defense lawyer seeks on cross examination to impeach (i.e. undermine the credibility of) the adversary's witness, including a defendant who chooses to testify in her own defense. FRE 609 allows the opposing party to impeach the other side's witness with that witness's prior felony convictions and with misdemeanor convictions involving dishonesty or false statement, unless the judge determines that the prejudice caused by admitting this prior crimes evidence would substantially outweigh its probative value. Juvenile adjudications may also be used to impeach witnesses other than the defendant (Fed. R. Evid. 609(d); Davis v. Alaska, 415 US 308, 1974); Huddleston $v$. United States, 485 US 681, 1988).

While one hundred years ago, a witness could only be impeached with prior convictions for crimes involving dishonesty or false statements (crimi falsi), the trend in US law is in the direction of making it easier to impeach with past crimes and bad acts. Some state evidentiary rules are even more liberal than the federal rule. For example, unlike FRE 609, California evidence law does not prohibit impeaching witnesses with convictions more than ten years old. Under Illinois law, any felony can be admitted to impeach a witness's credibility, as long as the probative value of the impeachment evidence outweighs its prejudicial effect (People v. Montgomery, 268 N.E.2d 695 (Ill, 1971)).

Because of the "unique risk of prejudice" to a defendant who testifies, FRE 609 provides special protection against impeachment with prior crime or bad act evidence for a testifying defendant than for other witnesses (Fed. R. Evid. 609(a) advisory committee's note). FRE includes a presumption against permitting a testifying defendant to be impeached with evidence of his prior crimes or bad acts. To overcome that presumption in favor of exclusion, the government must show that the prior conviction's probative value "out-weighs its prejudicial effect to that defendant” (Fed. R. Evid. 609(a)(1)(b); Friedman, 1991)). California provides no special protection to a testifying defendant, who may be impeached just like any other witness. At the other end of the spectrum, Hawaii does not admit prior conviction evidence to attack the defendant's credibility unless the defense has "introduced testimony for the purpose of establishing the defendant's credibility as a witness" and the defendant's prior conviction was for a crime of dishonesty (Haw. R. Evid. 609(a)).

New York State is also more protective of the defendant's prior record than FRE 609. At New York's well-known pretrial "Sandoval Hearing," the trial judge must weigh the probative value of prior crimes evidence against prejudice to the defendant. In People v. Bermudez, a New York state court crafted a compromise impeachment rule where, under appropriate circumstances, the judge can permit the prosecutor to ask the testifying defendant whether he has ever been convicted of a felony (People v. Bermudez, 414 N.Y.S.2d 645 (N.Y. Sup. Ct. 1979)). If the answer is yes, the defendant does not have to disclose the nature or details of the prior crime.

\section{Impeachment with Expunged Convictions}

Suppose a witness's conviction has been expunged; does that mean that it cannot be used to impeach that witness? Allowing impeachment would undermine the value of expungement, whose purpose is to permit a convicted person to put a conviction behind him after passage of a specified number of years without another conviction (United States v. Doe, 935 F. Supp. 478 (S.D.N.Y. 1996). FRE 609 provides that both convictions and bad acts more than ten years old cannot be used to impeach a witness. However, consider the case of a prosecution witness who is giving damaging testimony against the defendant. The defendant could make a strong argument that the Sixth Amendment right to confront the evidence against her must 
mean that she has the right to impeach the prosecution's witnesses' credibility by bringing out the witness's expunged convictions. After all, expungement does not mean that the crime was not convicted; rather it reflects a judgment that enough time has passed since the conviction that the convict should be permitted to get on with his life without the burden of a criminal stigma. Lower courts have taken different positions on this issue. While many states do not allow a witness to be impeached with an expunged conviction, a minority of states do. For example, in Wal-Mart Stores, Inc. v. Regions Bank Trust Dept., the Arkansas Supreme Court reversed the trial court's ruling that a prosecution witness could not be impeached with evidence of an expunged felony theft conviction (Wal-Mart Stores, Inc. v. Regions Bank Trust Dept., 347 Ark. 826, 2002). The court based its reasoning on the fact that the expunged conviction involved a crime of dishonesty and the expungement was based upon the passage of time, not on an affirmative finding of rehabilitation. The Supreme Court's decision in Davis $v$. Alaska would seem to support the position that the defendant has a right to impeach a prosecution witness with evidence of even expunged convictions. In Davis, the Court held that the state's interest in protecting the confidentiality of a witness's juvenile delinquency adjudication is subordinate to the criminal defendant's right of confrontation (Davis v. Alaska, 415 US 308, 1974). Likewise, the Court would probably hold that a witness's interest in hiding information about an expunged conviction must give way to the defendant's confrontation right.

It's another matter whether a defense witness or the defendant himself can be impeached with an expunged conviction. The prosecution wishing to impeach a defense witness has no constitutional right to rely on, as constitutional rights belong to individuals, not the state. The prosecution has to argue that, as a matter of policy, it ought to be permitted to impeach the defense witness whose prior conviction has been expunged, just as it can impeach a defense witness with prior bad acts for which she was never convicted or ever charged. Assuming that the defendant could impeach the prosecution's witness with an expunged conviction, fairness to the state would count in favor of allowing impeachment of defense witnesses with expunged convictions.

\section{Impact on the Defendant's Decision to Testify}

The defendant has an absolute right to testify on her own behalf. If the defendant can be impeached with her prior convictions and bad acts, she may be deterred from testifying out of fear that if the jurors hear her prior convictions, they will not believe her testimony and, worse, they might become prejudiced against her in assessing her guilt on the present charges. Even if she has a plausible defense, she may decide that the best course is to plead guilty to a lesser charge rather than risk a more severe sentence if convicted at a trial. Even the prospect of an expunged conviction being disclosed to the jury might convince a defendant not to testify. In People v. Strasser, a New York court held that a trial judge did not abuse his discretion by allowing the prosecution to impeach the defendant with an expunged larceny conviction. The court noted that "the expungement of defendant's conviction was not proven to constitute a dismissal of that charge on the merits, nor does it alter the fact that a criminal act was perpetrated by him" (People $v$. Strasser, 249 A.D.2d 781, 1998).
A defendant with a prior sex offense conviction is especially unlikely to testify on his own behalf, even more so if the current charge is also a sex crime. While the judge will explain to the jury that the past conviction(s) is not being admitted to show the defendant's propensity for criminality, but only to shed light on the credibility of his testimony, there is a serious risk that the jurors will be so alarmed and repulsed by this information that, consciously or unconsciously, they will be more likely to find the defendant guilty in the present case, even though the current charge is not for a sex offense (Rickert, 2010). This puts added pressure on defendants with prior convictions to plead guilty.

\section{Comparison with European Countries}

The continental European countries in most cases allow the trier of fact, including lay judges, to see the defendant's prior criminal record. Apparently, Europeans jurists believe that a criminal record's relevance to guilt and innocence outweighs a criminal defendant's right to privacy, despite the high priority they give to criminal record confidentiality. In contrast to the common law countries, which fear that lay jurors may not be willing or able to assess guilt fairly if they have knowledge of the defendant's prior convictions, civil law jurists believe that professional judges will properly weigh the relevance of a defendant's prior convictions. In those European countries that use mixed panels of professional and lay jurors in some criminal cases, there is no evidentiary rule preventing the lay jurors, while they are deciding the defendant's guilt or innocence, from learning about the defendant's prior criminal history. Indeed, civil law countries do not make the sharp distinction between the adjudicatory and sentencing phases of a criminal trial.

In $X v$. Denmark, the European Commission of Human

Rights considered a challenge to prior crime evidence being introduced into the guilt phase of the criminal trial. In their appeal on two counts of rape, the prosecutor had included evidence of X's prior rape conviction in the file submitted to the Commission, which then determined whether the case was admissible to the European Court of Human Rights. The Commission considered whether prior crimes evidence violated Article 6 of the European Convention on Human Rights. Article 6 guarantees that "[i]n the determination of his civil rights and obligations or of any criminal charge against him, everyone is entitled to a fair and public hearing within a reasonable time by an independent and impartial tribunal established by law." The Commission observed that in a number of European countries, prior crimes evidence is admitted at trial, and ultimately decided that "the Commission is not prepared to consider such a procedure as violating... the Convention, not even in cases where a jury is to decide on the guilt of an accused" ( $X$ v. Denmark (Application No 2518/65) (1965) ECHR 3). The Commission seemed satisfied that the professional judges on the Court would be able and willing to properly counsel their lay colleagues on the weight that should be given to prior conviction evidence.

\section{Conclusion}

In contrast to the pre-trial detention and sentencing stages of the criminal process where the relevance of prior criminal record has not been controversial, the admissibility of a defendant's criminal record at trial has always generated controversy.

When it came to the state branding someone a criminal and 
imposing punishment via its court process, judges were reluctant, even unwilling, to infer present wrongdoing from past wrongdoing. Implicitly, they were unwilling to adopt such a hard-wired view of character-once a criminal always a criminal. John Henry Wigmore, author of the great Anglo-American evidence treatise of the early $20^{\text {th }}$ century (1904), explains that character evidence has the potential to unfairly prejudice the defendant: "Here, however, a doctrine of Auxiliary Policy... operates to exclude what is relevant - the policy of avoiding the uncontrollable and undue prejudice, and possible unjust condemnation, which such evidence might induce" (Wigmore, 1923).

But what the common law gave with one hand, it took away with the other. The presumption against the admissibility of the defendant's prior crimes to prove guilt of present charges was undermined by broad exceptions. In presenting the state's case against the defendant, the prosecutor can introduce the defendant's criminal record if she can persuade the trial judge that one or more exceptions apply and, if they do, that the probative value of the prior crimes evidence outweighs its prejudicial effect. The trend is toward more liberal admissibility of prior convictions and even prior criminal conduct. The modern view is said to be that a witness with past convictions "may be less likely to testify truthfully than a law-abiding citizen" (Weinstein \& Berger, 2006). The special evidentiary rules permitting admissibility of prior sex offenses to prove propensity to commit the charged sex offense is the most extreme example of this trend. This is obviously not good news for a defendant who would like to testify, but who fears that his prior crimes will have a prejudicial effect on the jury.

Continental European criminal justice systems have not been much concerned with the possible prejudice to defendants that may occur if the trier of fact knows about the defendant's prior criminal record while considering guilt or innocence on current charges. ${ }^{4}$ Indeed, European procedure does not make a sharp distinction between the guilt determining phase of a trial and the sentencing phase. Thus, the prior record, which is clearly relevant to sentencing, is placed in the same file that is used in determining guilt. This may not have been considered a problem because European countries have great confidence in their professional judges' ability not to give undue weight to past crimes evidence. Even when mixed judge and lay panels are used in criminal cases, the judges are probably trusted to properly counsel their lay colleagues on the appropriate weight to give prior crimes evidence.

\section{Acknowledgements}

Grateful thanks to Dimitra Blitsa, Alessandro Corda, Jonathan Fayer, Benjamin Goldberg, Elena Larrauri, Claire Tan and Marlen Vesper-Graske.

\section{REFERENCES}

18 U.S.C. § 922 (2006). It shall be unlawful for any person... who has been convicted in any court of a crime punishable by imprisonment for a term exceeding one year... to ... possess in or affecting commerce, any firearm or ammunition; or to receive any firearm or ammunition which has been shipped or transported in interstate or foreign commerce.

${ }^{4}$ Greece seems to be an exception. The court can only find out about the defendant's prior record after it finds him guilty. The prior record is then only considered for sentencing purposes.
Advisory Comm. Note to 1991 404(b).

Davis v. Alaska, 415 US 308, 319 (1974).

Fed. R. Evid. 403.

Fed. R. Evid. 404(b) Evidence may be admissible for another purpose, such as proving motive, opportunity, intent, preparation, plan, knowledge, identity, absence of mistake, or lack of accident.

Fed. R. Evid. 413 In a criminal case in which the defendant is accused of sexual assault, evidence of the defendant's commission of another offense or offenses of sexual assault is admissible, and may be considered for its bearing on any matter to which it is relevant.

Fed. R. Evid. 609(a) advisory committee's note.

Fed. R. Evid. 609(d); cf. Davis v. Alaska, 415 US 308 (1974). Holding that a defendant has a Sixth Amendment confrontation clause right "to probe into the influence of possible bias in the testimony of a crucial identification witness," including his juvenile record.

Fed. R. Evid.414, In a criminal case in which the defendant is accused of an offense of child molestation, evidence of the defendant's commission of another offense or offenses of child molestation is admissible, and may be considered for its bearing on any matter to which it is relevant.

Friedman, R. D. (1991). Character Impeachment Evidence: PsychoBayesian Analysis and a Proposed Overhaul, 38 U.C.L.A. L. Rev. 637, 642-643. The prohibition against propensity evidence is deeply engrained. Given the prohibition, a violation of it must be considered prejudicial without regard to whether, in determining the facts, the jury likely relied more on the evidence than would be rational; any reliance at all is deemed improper. And because the propensity evidence is likely to affect the jury powerfully, both in guiding its fact finding and in altering the effective burden of proof, the prejudice is often extreme. Nevertheless, evidentiary rule makers have concluded that, because the jury is so dependent on the testimony of witnesses, it must have a relatively full base of information on which to assess their credibility.

Haw. R. Evid. 609(a).

Huddleston v. United States, 485 US 681, 689 (1988). Holding that under FRE 404(b), "similar act evidence is relevant only if the jury can reasonably conclude that the act occurred and that the defendant was the actor.

Kalven, H., \& Zeisel, H. (1966). The American Jury.

Leonard, D. P. (1995). The Federal Rules of Evidence and the Political Process, 22 Fordham Urb. L.J. 305, 341.

Manual of Model Criminal Jury Instructions for the District Court of the Eight Circuit § 2.09 (2011).

Michelson v. United States, 335 US 469, 475-76 (1948). Holding that, subject to the trial court's discretion to prevent abuse, the prosecution may impeach the defendant's character witness by asking the witness if she is aware of the defendant's prior convictions.

Natali Jr., L. M., \& Stigall, R. S. (1996). Are you going to arraign his whole life? How sexual propensity evidence violates the due process clause, Loy. U. Chi. L.J., 28, 3-4.

Ojala, E. D. (1999). Propensity evidence under rule 413: The need for balance, Wash. U. L.Q, 77, 949.

Old Chief v. United States, 519 US 172 (1997).

Park, R. C., et al. (2011). Evidence law: A student's guide to the law of evidence as applied in American Trials 164 (3rd ed.).

People v. Bermudez, 414 N.Y.S.2d 645 (N.Y. Sup. Ct. 1979).

People v. Bierenbaum, 748 N.Y.S.2d 563, 584 (N.Y. App. Div. 2002) (quoting People v. Linton, 561 N.Y.S.2d 259, 260 (N.Y. App. Div. 1990) (internal quotation marks omitted).

People v. Dyes, 122 A.D.2d 69 (N.Y. App. Div. 1986). Affirming the admissibility of children's testimony of defendant's prior abuse of their mother, defendant's wife, in the months before she was murdered.

People v. Mixon, 203 A.D.2d 909, 909-10 (N.Y. App. Div. 1994). Affirming the admissibility of evidence of the defendant's prior abuse of domestic partner because it is relevant to proving defendant's motive.

People v. Molineux, 168 N.Y. 264, 293 (1901).

People v. Montgomery, 268 N.E.2d 695, 698-99 (Ill, 1971).

People v. Strasser, 249 A.D.2d 781 (1998). 


\section{J. B. JACOBS}

President's Task Force on Victims of Crime (1982). President's task force on victims of crime final report (p. 9). Washington DC: US Government Printing Office.

Rickert, J. T. (2010). Denying defendants the benefit of a reasonable doubt: Federal rule of evidence 609 and past sex crime convictions. Journal of Criminal Law and Criminology, 100, 213.

Spencer v. Texas, 385 US 554 (1967).

State v. Beck, 536 S.E.2d 679, 683 (S.C. 2000) (citing State v. Kennedy, 528 S.E.2d 700 (S.C. Ct. App. 2000)).

State v. Cheeseboro, 346 S.C. 526, 540 (2001)

United States v. Connelly, 874 F.2d 412, 416 (7th Cir. 1989). Similar act evidence offered on this theory-that the prior and charged offenses are so strikingly similar that the same person or persons probably had a hand in both-is frequently admitted under the identity exception to Rule 404(b), but is commonly referred to and offered as modus operandi evidence.

United States v. Crowder, 141 F.3d 1202, 1209 (D.C. Cir. 1998). A defendant's offer to stipulate to an element of an offense does not render the government's other crimes evidence inadmissible under Rule 404(b) to prove that element, even if the defendant's proposed stipulation is unequivocal..

United States v. Doe, 935 F. Supp. 478 (S.D.N.Y. 1996). Granting the defendant an expungement based in part on the significant negative impact of defendant's prior conviction on his ability to find gainful employment for the past twenty years.

United States v. Gabe, 237 F.3d 954 (8th Cir. 2001).

United States v. Hurley, 755 F.2d 788, 790 (11th Cir. 1985) Holding that a subsequent act, as well as a prior act, can be used to show intent under Rule 404(b).

United States v. Johnson, 458 F. App'x 727, 728 (10th Cir. 2012). The prosecution sought to introduce evidence that, on a prior occasion,
Johnson grabbed a female clerk's buttocks, and then pressed his crotch against the female clerk's buttocks while making a sexual comment and touching her breasts with his hands.

United States v. Richardson, 764 F.2d 1514, 1522 (11th Cir. 1985).

United States v. Rogers, 587 F.3d 816, 822 (7th Cir. 2009). Rule 404(b) identifies the propensity inference as improper in all circumstances, and Rule 413 makes and exception to that rule when past sexual offenses are introduced in sexual assault cases.

United States v. Simon, 453 F.2d 111, 115 (8th Cir. 1971). Once the defense has introduced the entrapment or procuring agent defense, the Government may proceed with relevant evidence to the contrary.

United States v. Williams, 238 F.3d 871 (7th Cir. 2001). Holding that evidence of prior bad acts to prove knowledge and intent elements of a criminal offense is admissible even though defendant had offered to stipulate to these mental elements.

Violent Crime Control and Law Enforcement Act of 1994, Pub. L. No.103-322, §320935(a), 108 Stat. 1796, 2135-37 (codified at 42 U.S.C. $\S \S 13,701$ et seq.).

Wal-Mart Stores, Inc. v. Regions Bank Trust Dept., 347 Ark. 826 (2002). We conclude that, in the absence of a finding that [defendant] had been rehabilitated, the trial court's decision to exclude evidence of her conviction under Rule 609(c) was erroneous.

Weinstein, J., \& Berger, M. A. (2006). Weinstein's Federal Evidence $\S$ 404.21[1][a].

Wigmore, J. H. (1923). A treatise on the Anglo-American system of evidence in trials at common law: Including the statutes and judicial decisions of all jurisdictions of the United States and Canada (2nd ed., p. 272).

X v. Denmark (Application No 2518/65) (1965). ECHR 3 (commission not yet ready to interpret Article 6 of the Convention). 